\title{
Photodegradation of Real Pharmaceutical Wastewater with Titanium Dioxide, Zinc Oxide, and Hydrogen Peroxide During UV Treatment
}

\author{
Wasi Z Khan ${ }^{1}$,Imad Najeeb ${ }^{2}$,Shagufta Ishtiaque ${ }^{3}$, Suraiya Jabeen ${ }^{4}$ \\ $\left({ }^{1}\right.$ Military Technological College, Muscat, Oman:) \\ ( ${ }^{2}$ PakOasis Industries (Pvt) Ltd, Karachi, Pakistan) \\ $\left({ }^{3}\right.$ Department of Chemical Engineering, University of Karachi, Pakistan) \\ ${ }^{4}$ Institute of Environmental Studies, University of Karachi, Pakistan)
}

\begin{abstract}
This paper presents the photocatalytic degradation of real pharmaceutical wastewater from Abbot Laboratories (Private) Limited, Karachi, Pakistan, using $\mathrm{TiO}_{2}, \mathrm{ZnO}$, and $\mathrm{H}_{2} \mathrm{O}_{2}$. The pretreated sample wastewater was used for degradation experiments and tests were carried out at $38{ }^{\circ} \mathrm{C}$ under $\mathrm{pH}$ of 9 and 4 in a stirrer bath reactor equipped with eight ultraviolet tubes. The use of this technique is common in removal of the organic, inorganic pollutants and pathogens. Optimal conditions were selected from reported results of the researchers on advanced oxidation processes (AOPs) for removal of residual pharmaceuticals from real pharmaceutical wastewater. The three catalysts (Titanium dioxide, zinc oxide, and $\mathrm{TiO}_{2} / \mathrm{H}_{2} \mathrm{O}_{2}$ ) used in this study are effective catalysts in photocatalytic degradation of real pharmaceutical wastewater. The maximum degradation achieved was $45.11 \%$ by combined use of $\mathrm{TiO}_{2}$ and $\mathrm{H}_{2} \mathrm{O}_{2}$ at $38{ }^{\circ} \mathrm{C}$ and $\mathrm{pH}$. The degradation improved at higher $\mathrm{pH}$ with Zinc oxide and Titanium oxide. The results indicate that for real pharmaceutical wastewater, combined use of $\mathrm{TiO}_{2} / \mathrm{H}_{2} \mathrm{O}_{2}$ is comparatively more effective than $\mathrm{ZnO}$ and $\mathrm{TiO}_{2}$ alone. The degradation of the pharmaceutical wastewater followed pseudo-first-order kinetics. The reaction rate constant was $0.00148 / \mathrm{min}$ for $\mathrm{TiO}_{2} / \mathrm{H}_{2} \mathrm{O}_{2}$. This study demonstrates that for real pharmaceutical wastewater reacts differently to catalyst than synthetic pharmaceutical wastewater, or formulated wastewater.
\end{abstract}

Keywords:-Hydrogen peroxide, Pharmaceutical wastewater, Photocatalytic degradation, Titanium dioxide, Ultra violet light, Zinc oxide

\section{INTRODUCTION}

The pharmaceuticals are found in drug manufacturing wastewater, hospital wastewater, and industrial wastewater of pharmaceutical origin. The pharmaceutical usually consist of biologically active substances designed as lipophilic and are resistant to biodegradation. In aquatic media these substances if discharged to the environment, have potential for accumulation and persistence in the environment. Though they appear at low concentrations, but still may impose serious effects on the environment. During last two decades researchers have focused their attention in searching suitable technologies to destroy the xenobiotic substances and recently been able to report advanced oxidation processes (AOPs) as highly efficient treatment process for pharmaceutical wastewater.

Among many processes the ozone oxidation is adapted as part of the treatment at several water production plants. Treatment of pharmaceutical wastewater by AOPs is expensive, hence photocatalysis is an option considered widely by researchers. In recent years photocatalytic degradation of pharmaceutical wastewater has received attention of the scientific community. The results of past research carried out on real pharmaceutical effluent are comparable to this study; however, the results of studies on aqueous solution, synthetic wastewater, formulation effluent, synthetic wash-water from antibiotics packaging distilled water, industrial wastewater of pharmaceutical origin, hospital wastewater, synthetic wash-water from medium scale drug manufacturing plant, biologically pre-heated pharmaceutical wastewater, actual wash-water from ointment manufacturing plant, effluent from bulk drug manufacturing plant, municipal wastewater, and secondary treated domestic effluent are worth considering. The previous findings on aqueous system indicate degradation of wastewater by $\mathrm{TiO}_{2}$ and $\mathrm{UV}$ alone is negligible [1] and that coupling of $\mathrm{TiO}_{2}$ with UV greatly enhance degradation rates [2-4]. Only UV processes require long irradiation time [5] and only $\mathrm{TiO}_{2}$ require high catalyst loading [6]. The variables affecting the degradation rates are catalyst loading, $\mathrm{pH}$ and temperature of solution/wastewater, irradiation time and intensity, and use of additional catalyst like $\mathrm{H}_{2} \mathrm{O}_{2}$ with and without $\mathrm{Fe}^{2+}$. The particle size and surface area/ ${ }_{\mathrm{BET}}$ of the catalyst $\left(\mathrm{TiO}_{2}\right)$ is an important parameter too [3]. The total organic carbon (TOC) removal rate depends on refractory character of the organic-inorganic wastewater content. 
Fatemeh reports high degradation of analgesics in water at $\mathrm{pH} 12$ and $50{ }^{\circ} \mathrm{C}$ [7] whereas, Liming found degradation between $\mathrm{pH}$ of 3.5 and 9.5 [1]. The synthetic wastewater made from human and veterinary antibiotics show that degradation increases with increasing $\mathrm{pH}$ ( $\mathrm{pH}$ range 7-12), $\mathrm{H}_{2} \mathrm{O}_{2}$ enhance performance $[8,9]$. The results of Kaniou et al on Sulfamethzine in distilled water indicate higher removal performance of $\mathrm{H}_{2} \mathrm{O}_{2}$, and $\mathrm{ZnO}$ was more active than $\mathrm{TiO}_{2}$ [10]. 90\% removal of Diclofenac from distilled water is reported by $\mathrm{TiO}_{2}$ after 60 minutes of irradiation [11]. 55\% COD removal from industrial wastewater of pharmaceutical origin is reported by San Sebastian by using $\mathrm{H}_{2} \mathrm{O}_{2}$ at $\mathrm{pH} 4$ [12]. Xing et al found 94\% color and 73\% COD removal with $\mathrm{Fe}^{2+} / \mathrm{H}_{2} \mathrm{O}_{2}$ at $\mathrm{pH} 5$ from biologically pre-heated pharmaceutical wastewater [13]. Kulik et al reports $87 \%-96 \%$ COD removal from actual wash water from ointment manufacturing plant with $\mathrm{Fe}^{2+} / \mathrm{H}_{2} \mathrm{O}_{2}$ [14]. Augmentation of $\mathrm{TiO}_{2}$ by $\mathrm{H}_{2} \mathrm{O}_{2}$ is reported by many researchers [15-18] and now it is believed that presence of $\mathrm{H}_{2} \mathrm{O}_{2}$ enhances degradation performance of the catalyst [9]. The generation of the $\mathrm{OH}$ radicals in the $\mathrm{UV} / \mathrm{H}_{2} \mathrm{O}_{2}$ occurs via reaction (1) [19].

$\mathrm{H}_{2} \mathrm{O}_{2}+\mathrm{h} v \rightarrow 2 \cdot \mathrm{OH}$

The photogenerated electrons can recombine and make their ways to the surface of $\mathrm{TiO}_{2}$, where they can react with species adsorbed onto the catalyst surface.

$\mathrm{h} v^{+}+\mathrm{H}_{2} \mathrm{O} \rightarrow \mathrm{OH}+\mathrm{H}^{+}$

$\mathrm{h} v^{+}+\mathrm{OH}^{-} \rightarrow \mathrm{OH}$

Organics $+\mathrm{h} v^{+} \rightarrow$ products

The photogenerated electrons can also combine with $\mathrm{O}_{2}$ and organics and produce:

$\mathrm{e}^{-}+\mathrm{O}_{2} \rightarrow \mathrm{O}_{2}^{-}$

Organics $+\mathrm{e}^{-} \rightarrow$ products

The produced hydroxyl radicals $(\mathrm{OH})$ and superoxide radical anion $\left(\mathrm{O}_{2}^{-\cdot}\right)$ can mineralize organics to water and $\mathrm{CO}_{2}$ (end products):

Organics $+\left((\cdot \mathrm{OH}), \mathrm{O}_{2}^{-\cdot}\right.$, etc. $) \rightarrow$

Only a few studies have been conducted on industrial wastewater of pharmaceutical origin employing $\mathrm{TiO}_{2}$ and $\mathrm{H}_{2} \mathrm{O}_{2}$ asthecatalystswithvaryingdegradationresults.Itisstillunclearthat how realpharmaceuticalwastewaterwouldrespon to photocatalytic activity of widely used catalysts. Thispaperreportsthefindingsoftheresearchworkemploying $\mathrm{TiO}_{2}, \mathrm{ZnO}$, and $\mathrm{H}_{2} \mathrm{O}_{2}$ and the performance of $\begin{array}{llllll}\text { photocatalytic } & \text { reactor } & \text { for } & \text { degradation } & \text { real }\end{array}$ pharmaceuticalwastewater.Theresultsofthisstudywouldaidtotheapplicationofnanophotocatalyst particles forremovalofcontaminantsfrompharmaceuticalwastewater.

\section{1 material}

\section{EXPERIMENTAL PROCEDURE}

Inthisstudy titanium dioxide powder (anatase) formandZincoxide (Dentam) were used as supplied.TheseChemicalsaresuppliedbyBDHwithpurityof $99.99 \%$ withtheaverageparticle sizeof $25 \pm$ 4nmandspecificsurfaceof55 $\quad 8 \quad \mathrm{~m}^{2} \quad \mathrm{~g}^{-1}$.The30\%AqueousSolutionofHydrogen peroxidewasalsosuppliedbyBDH.ThepHofthesampleinthereactionvesselwasadjusted withcalculatedvolume/weightof1NHClor1 NNaOH.Thestandardsolutionandreagentswere usedformeasuring $\begin{array}{llll}\text { theCODinclosed reflux } & \text { colorimeterasproposed } & \text { byAPHA } & \text { These }\end{array}$ catalystsareknownforoptimalcatalyticefficiencyandgoodinterparticlecontactsinwater[21].

\section{2 ultraviolet energy}

The

thecontaminantin sterilizesthewastewaterbydestroyingfivemajorgroupof $\mathrm{nm}$, and 50-150 Wis adequate forsyntheticand realpharmaceutical wastewater withanirradiationtimeof14hour.However,occurrence reportedwithinfirsthouroftreatment.Henceisthereasonforselectingoftheparametersforthis study.

\section{3 experimental setup}

The UV numberofeightUVlamptubes, manufacturedbyJiangsuShenXingPhotoelectricity Ltd.China, weresubmersedinthespeciallydesignedreactionvessel(diameter8 produce 88 Wofenergy.Thepretreatedsamplewastewaterwasplacedina cylinderverticalreactoractingasa photoreactioncell.Thecatalystpowderwassuspendedinthe sampleandthesolutionin thecellwaskepthomogenousbyconstantstirringwitha ofmostdegradationis stirrerandaerationbyusinganairpumpasshownintheFig. 1 (actualexperimentalrig).The schematic diagram 
experimental setupis shown in Fig. 2.The aerial view of the geometricalarrangementoftheUVtubesisshowninFig.3.Thepassingoftheairfacilitated

thewastewatercirculationaroundthereactionvesselinordertomaintainthereactiontemperature atthedesired value. Thiscellwasplacedinaconstanttemperaturebath.ThepHmeterandtemperatureprobewasinsertedintothecelltomonit orpHandtemperatureofthewastewater.

ThephotocatalyticdegradationwascarriedoutoversuspensionofTitaniumOxide,ZincOxide and $\mathrm{TiO}_{2} / \mathrm{H}_{2} \mathrm{O}_{2}$ underultravioletirradiation.

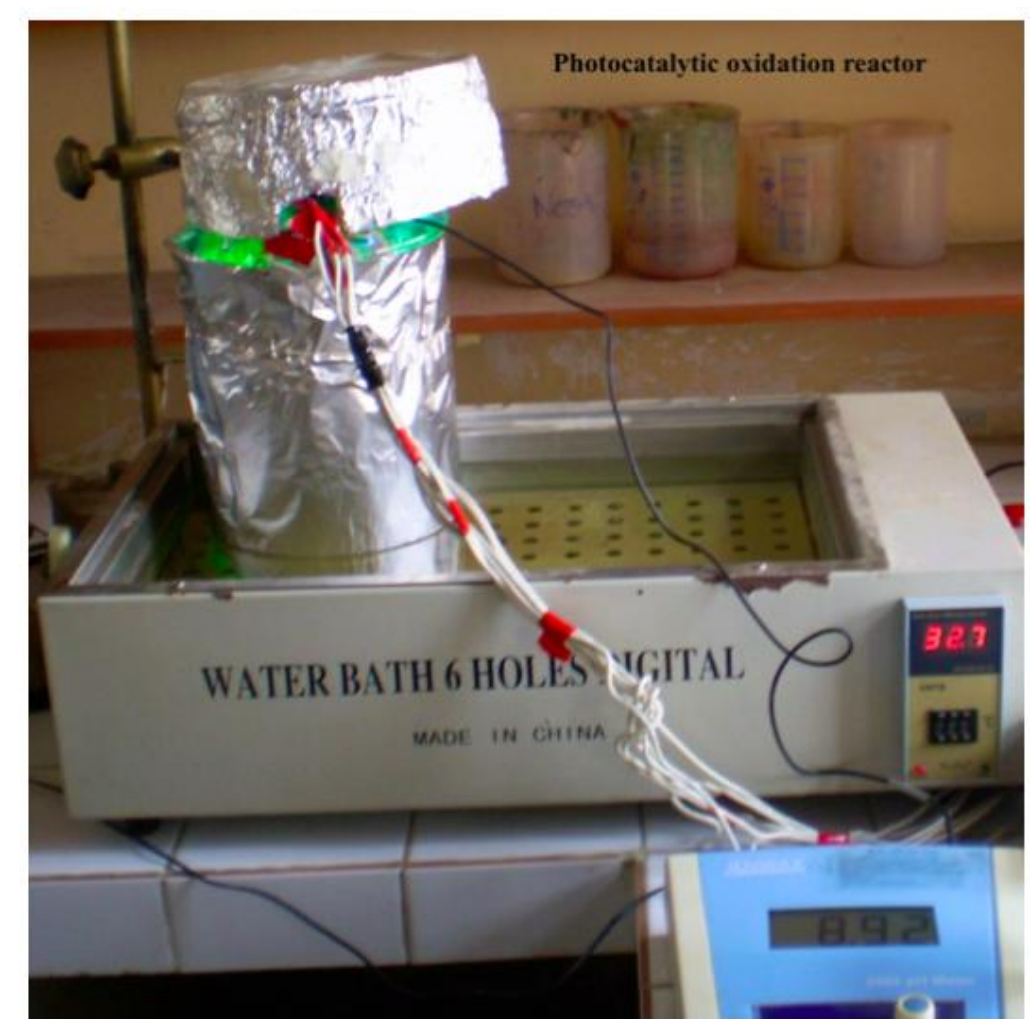

Fig. 1 photocatalytic oxidation reactor

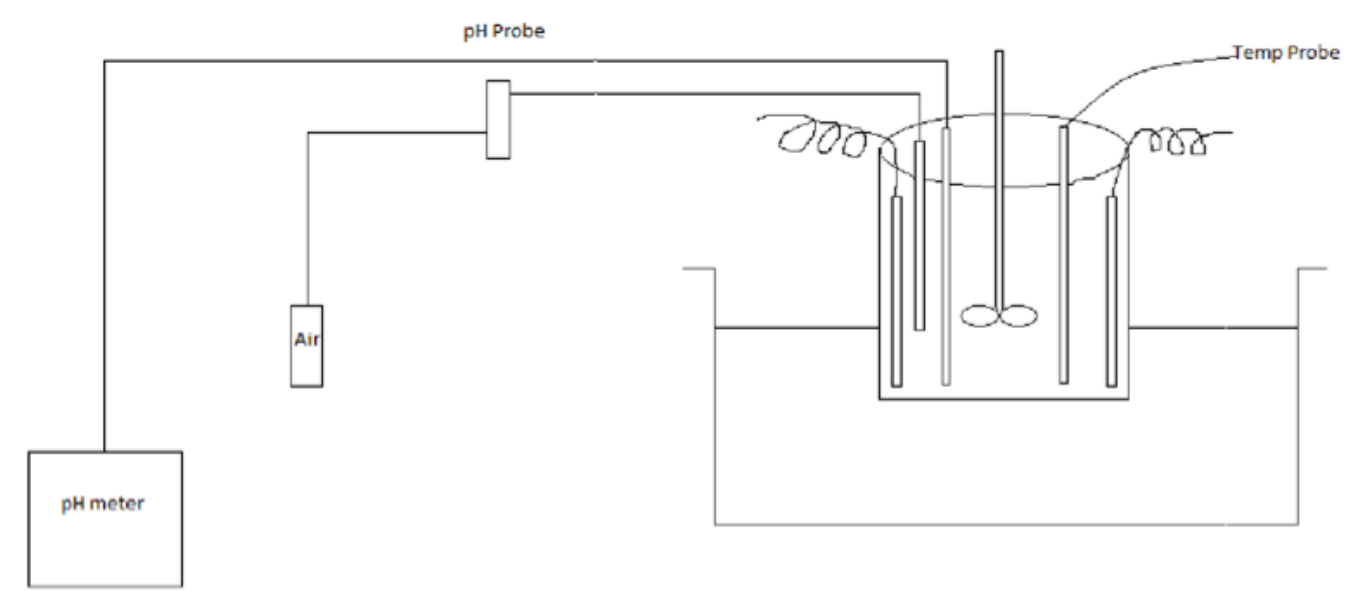

schematic diagram of the experimental set-up

Fig. 2 


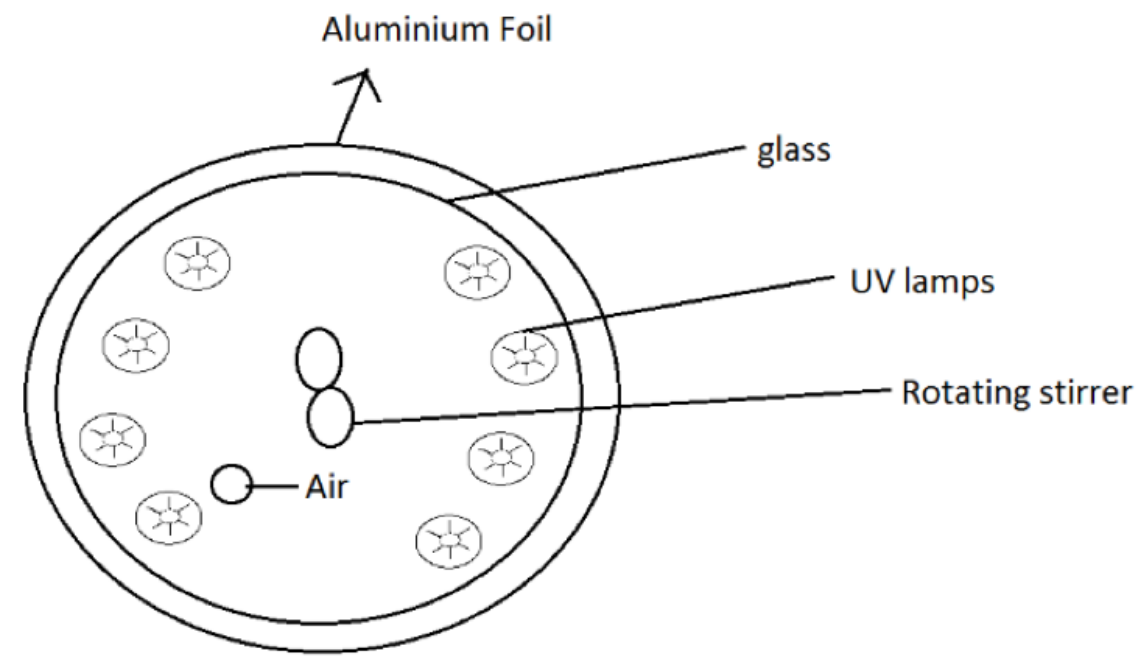

Fig. 3 the aerial view of the geometrical arrangement of the uv tubes in the reactor

TheSpectronic "Genesys 20" Spectrophotometer with wavelength range 325 to $1100 \mathrm{~nm}$, accuracy \pm $2.0 \mathrm{~nm}$ wasused to measure absorbance at $\lambda \max$ of $625 \mathrm{~nm}$. The rate of photodegradation iscalculatedinpercentagewithtimeofirradiation.Testswereconductedfor

variablessuchaspHofsamplewastewater,typeofcatalyst,andexposuretimeofUVlight.

\section{4 procedure}

The

optimumconcentrationof $\mathrm{TiO}_{2}$

reportedbyAlmudena[18,24]wasbetween 1.5 and $2.5 \mathrm{~g} / 1$, henceinallexperiments6goftitaniumdioxideor4gzincoxidewassuspendedin5literofthe

realpharmaceuticalwastewater which isplaced inaphotoreactioncell.Forexperiments with hydrogen peroxide, $2.4 \mathrm{ml} \quad \mathrm{H}_{2} \mathrm{O}_{2} 30 \%$ purity wasadded tosample wastewater. The suspensionwassubjectedtoirradiationunderUVlightfor2 hour.Thesuspensionwasstirredand aeratedthroughouttheexperiment.

Atregulartimeintervals, the $2 \mathrm{~cm}^{3}$ ofirradiatedsamplewastakenoutfromthereactionvessel withthehelpofmicrosyringe, andthenfilteredthroughMilliporefilterof $0.45 \mathrm{um}$ solidcatalyst.Usingcuvettestheabsorbanceofthesupernatantliquidismeasuredat $\lambda$ maxof $625 \mathrm{~nm}$.

toseparatethe

The antibacterial activities of the wastewater before and after the photocatalysis were measured by Abbot Laboratories using HPLC to determine the remaining concentration of the parent antibiotics (Sulfonamide, Fluroquinolones, Bacteriostatics, and Penicillingroup); analgesics (Acetaminophen); parent anti-inflammatory drugs (Diclofenac and Ibuprofen); and CNS stimulant (Caffeine). TABLE 1 lists the characteristics of sampled pharmaceutical wastewater from Abbot Laboratories, and TABLE 2 shows the minimum standard discharge limits for pharmaceutical effluents [25].

Table 1. Characteristics of Sampled Pharmaceutical Wastewater from Abbott Laboratories Limited

\begin{tabular}{|c|c|c|}
\hline Characteristics & Name of Drug & Value \\
\hline COD $\left(\mathrm{mgxl}^{-1}\right)$ & ------ & $168-240$ \\
\hline Antibiotics $\left(\mathrm{mgxl}^{-1}\right)$ & Sulfonamide & $0.02-0.52$ \\
\hline & Fluoroquinolones & $5-43$ \\
\hline & Bacteriostatic & $0.08-0.33$ \\
\hline & Penicillin group & $0.002-0.022$ \\
\hline Analgesics/Antipyretics & Acetaminophen & $10-28.55$ \\
\hline $\begin{array}{c}\text { Anti-inflammatory } \\
\text { drugs }\end{array}$ & Diclofenac & $0.01-480$ \\
\hline & & $0.47-885$ \\
\hline CNS Stimulant & Ibuprofen & $2.8-10.56$ \\
\hline TDS $\left(\mathrm{mgxl}^{-1}\right)$ & Caffeine & $980-1240$ \\
\hline TSS (mgxl & $-1)$ & $105-200$ \\
\hline $\mathrm{P}^{\mathrm{H}}$ (dimensionless) & ------ & $7.4-7.8$ \\
\hline Temperature $\left({ }^{\mathrm{O}} \mathrm{C}\right)$ & ------ & $24-30$ \\
\hline
\end{tabular}


Table 2. Minimum Standard Discharge Limits for Pharmaceutical Effluents [25]

\begin{tabular}{|c|c|}
\hline Parameter & Composition $\left(\mathrm{mgxl}^{-1}\right)$ \\
\hline COD & 250 \\
\hline BOD $\left(3\right.$ days, $\left.27^{\mathrm{O}} \mathrm{C}\right)$ & $10-40$ \\
\hline Oil \& Grease & 10 \\
\hline TSS & 100 \\
\hline $\mathrm{P}^{\mathrm{H}}$ (dimensionless) & $6.0-$ \\
\hline Mercury & 0.01 \\
\hline Arsenic & 0.20 \\
\hline Chromium $\left(\mathrm{Cr}^{6+}\right)$ & 0.10 \\
\hline Lead & 0.10 \\
\hline Cyanide & 0.10 \\
\hline Phenolics $\left(\mathrm{C}_{6} \mathrm{H}_{5} \mathrm{OH}\right)$ & 1.00 \\
\hline Chromium $\left(\mathrm{Cr}^{6+}\right)$ & 0.10 \\
\hline Sulphides $($ as S) & 2.10 \\
\hline Phosphates $($ as $\mathrm{P})$ & 5.0 \\
\hline
\end{tabular}

Each culture tubes were incubated for 12 hours at $38{ }^{\circ} \mathrm{C}$. After the incubation, the bacterial growth was measured using the optical density at $625 \mathrm{~nm}$. All bio-assessment tests were repeated for accuracy. The optical density value was converted to growth inhibition, I, and, was calculated in terms of changes in absorption spectra. The degradation efficiency I (\%) was calculated as:

$\mathrm{I}=[\mathrm{A}]_{\mathrm{o}}-[\mathrm{A}]_{\mathrm{t}} /[\mathrm{A}]_{\mathrm{o}} \times 100$

Where $[\mathrm{A}]_{\mathrm{o}}$ is the initial value and $[\mathrm{A}]_{\mathrm{t}}$ after any irradiation time. All experiments were carried out at two $\mathrm{pH}$ of sample with different photo catalyst. For accuracy of results the absorbance at a given time was compared with a calibration curve. The calibration plot was obtained by using a known percentage of real pharmaceutical wastewater. The calibration of spectrophotometer was done using manual procedure outlined in Spectronic "Genesys 20" and solutions were prepared from BDH products.

\section{RESULTS AND DISCUSSIONS}

\subsection{Effect of Catalyst Type}

The results presented in Fig. 4 shows effect of catalyst as an oxidant on degradation ofreal pharmaceuticalwastewaterbyphotoxidationprocessatconstantpH9andFig.5showseffectof $\mathrm{pH}$ on degradation ofwastewater withTiO $\mathrm{F}_{2}$ The wastewater waseffectively degraded using titaniumdioxideorzincoxideunderpHof9.Themaximumdegradationachievedwithin120 minutesof irradiationtime, wasabout $33.23 \%$ byusing $\mathrm{TiO}_{2}$ and $40.23 \%$ byusingZnOat

TherearelimitedresearchfindingsontheuseofcatalystlikeZnO.Mostresearchershavefocused $\mathrm{TiO}_{2}, \mathrm{H}_{2} \mathrm{O}_{2}, \mathrm{Fe}^{2+} / \mathrm{H}_{2} \mathrm{O}_{2}$, andFe ${ }^{2+} / \mathrm{H}_{2} \mathrm{O}_{2} / \mathrm{UV}$. Theresultsof thisstudyarenotdirectly ontheuse of $38^{0} \mathrm{C}$. reportedfindingsdueto variationsin theparametersstudied.However,the effectivenessofthecatalyst canbediscussed duetosimilartrendinCODandTOCremoval efficiency. Kaniou reports that $\mathrm{ZnO}$ is more active $\begin{array}{llll}\text { than } & \mathrm{TiO}_{2}[10] . & \text { Theyachieved } & 90 \%\end{array}$ degradationin60minuteswhen $\mathrm{TiO}_{2}$ wascombinedwithSiO 2 . Whereas,Limingfoundmorethan 90\% pollutant's(paracetamolinaqueoussolution)degradationin80minutesatpH9.5byTiO 2 alone[1].Thistrendiscom parable toourfindings. Theeffectiveness of ZnOwashigherthan $\mathrm{TiO}_{2}$ atgiven pHandtemp. Reduced effectiveness of $\mathrm{TiO}_{2}$ isduetomediumpHandlower reaction temperature. Fatemeh found higher degradation at $50{ }^{0} \mathrm{C}$. At high $\mathrm{pH}$ formation of $\mathrm{OH}$ radicals is enhanced [7]. The higher reactivity of $\mathrm{ZnO}$ is attributed to the geometry and working conditions of the photo reactor. The saturation level of $\mathrm{ZnO}$ under given operating conditions is lower than $\mathrm{TiO}_{2}$. 


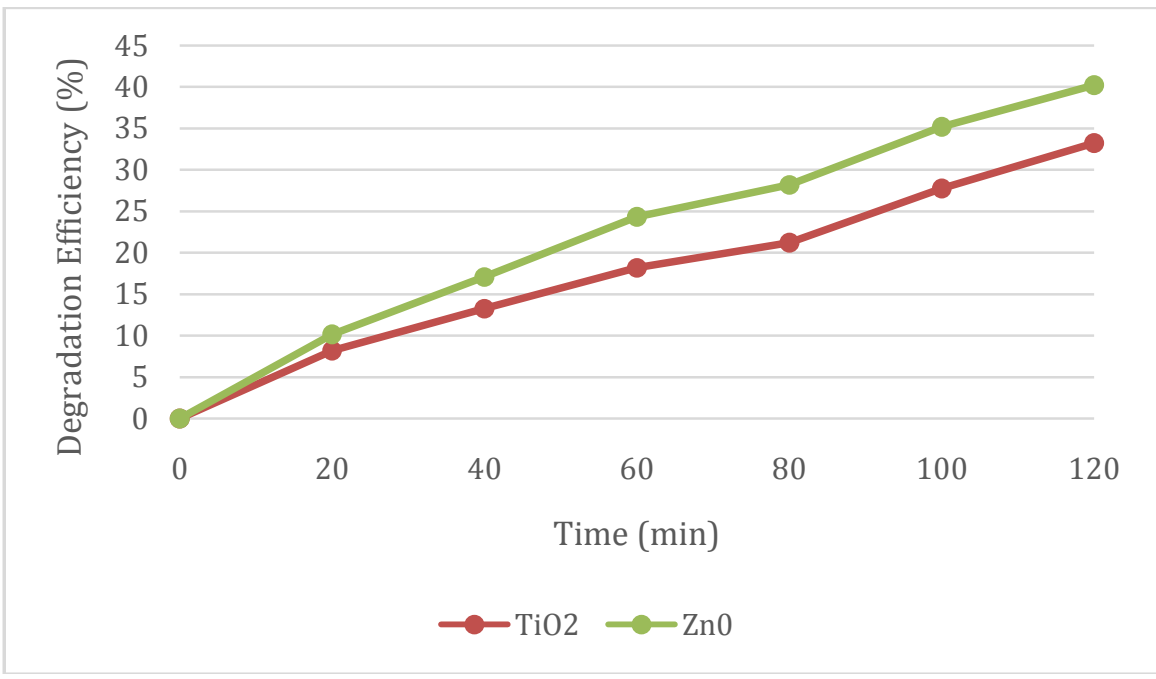

Fig.

4. The effect of catalyst on degradation of pharmaceutical waste water at $\mathrm{pH} 9.0, \mathrm{~T}=38^{\circ} \mathrm{C}$

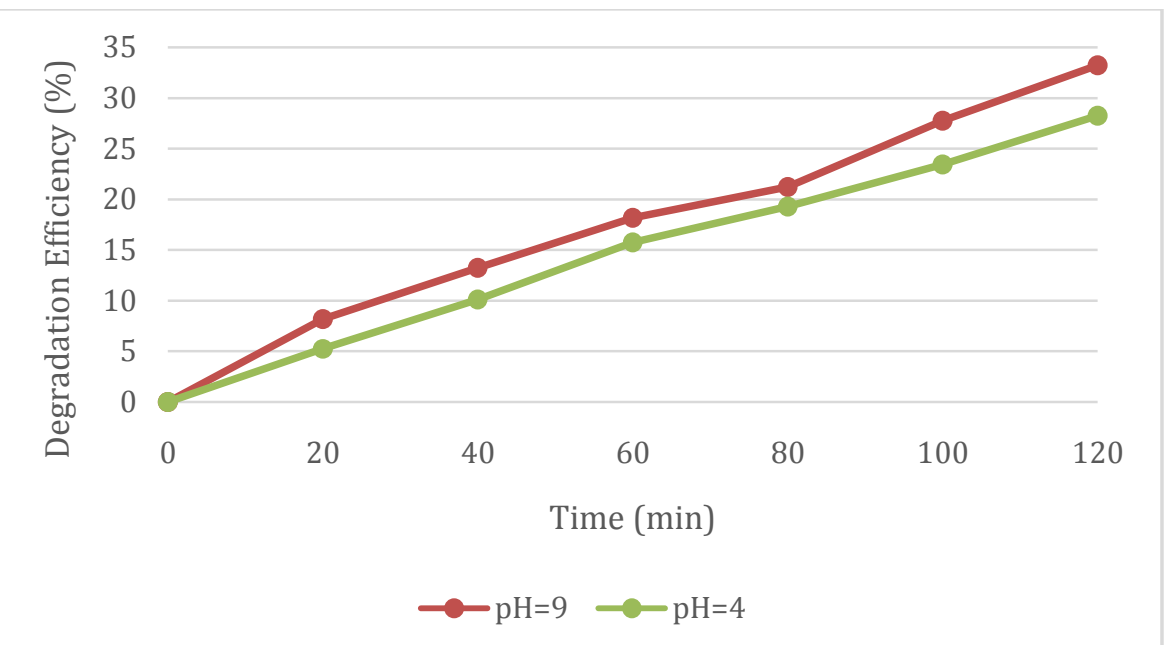

Fig. 5. The effect of $\mathrm{pH}$ on degradation of waste water with $\mathrm{TiO}_{2}\left(\right.$ Temperature $\left.=37^{\circ} \mathrm{C}\right)$

\subsection{Effect of pHwith additional catalyst $\mathrm{H}_{2} \mathrm{O}_{2}$}

TheeffectofpHondegradationofpharmaceuticalwastewaterby $\mathrm{TiO}_{2} / \mathrm{H}_{2} \mathrm{O}_{2}$

is showninFig.6.Themaximumdegradationachievedwithin120minutesofirradiationtime, atpH9wasabout

$45.11 \%$. Byaddingthecatalyst $\mathrm{H}_{2} \mathrm{O}_{2}$ to

$\mathrm{TiO}_{2}$, thedegradationwasincreasedby $12 \%$.Ithasbeen reportedbymanyresearchersthat $\mathrm{H}_{2} \mathrm{O}_{2}$ additionincreasesdegradationefficiencyofthecatalyst [22,26-30]. Yeon[ 30 ] foundmorethan99\%removalofamoxicillin fromaqueoussolution inthe presenceof $\mathrm{H}_{2} \mathrm{O}_{2}$. $\mathrm{Xiang}_{\text {- }}$ RongreportsthatFentonprocessismoreefficientthanUV/ $\mathrm{H}_{2} \mathrm{O}_{2}$ inthe absenceof $\mathrm{TiO}_{2}[6]$ asrateofreactionincreaseswith $\mathrm{H}_{2} \mathrm{O}_{2}$.

Itisprovedthatmorethan $90 \%$

degradationcanbeachievedinaqueoussolutionbutnotinrealpharmaceuticalwastewater.As real wastewater characteristics and chemistry of pollutants are significantly different than syntheticwastewateroraqueoussolution, it is $\quad$ expectedthatdegradationwouldvarywidely.Fig.7 $\quad$ and8 showperformanceofcatalystatconstantpH9 and4respectively.AtpH4 themaximum degradationachievedwithin 120 minutesofirradiationtime, wasabout $40.18 \%$.Itindicatedthat

pHplayedanimportantroleandthemoderatephotocatalysisinthepresenceof $\mathrm{H}_{2} \mathrm{O}_{2}$ isdueto enhancedabsorbanceofUVlightcapacitybythecompound; whichissimilartothefindingsof manyotherresearchers[12,14, 31].EvenwithFentonoxidationprocesswith $\mathrm{H}_{2} \mathrm{O}_{2}$, the maximum COD removal fromindustrialwastewater ofpharmaceutical origin was $55 \%$. Hence itisnot surprisingtoachieveamaximumdegradationof $45 \%$ usingrealpharmaceutical wastewater.A possibleexplanationforlowerdegradationcouldbe thatphotocatalyticreactioninrealwastewater 
producesseveralintermediateproductsandtheseproductsdonottransformintoCO $\mathrm{C}_{2}$ to

theextent transformedinaqueoussolution.

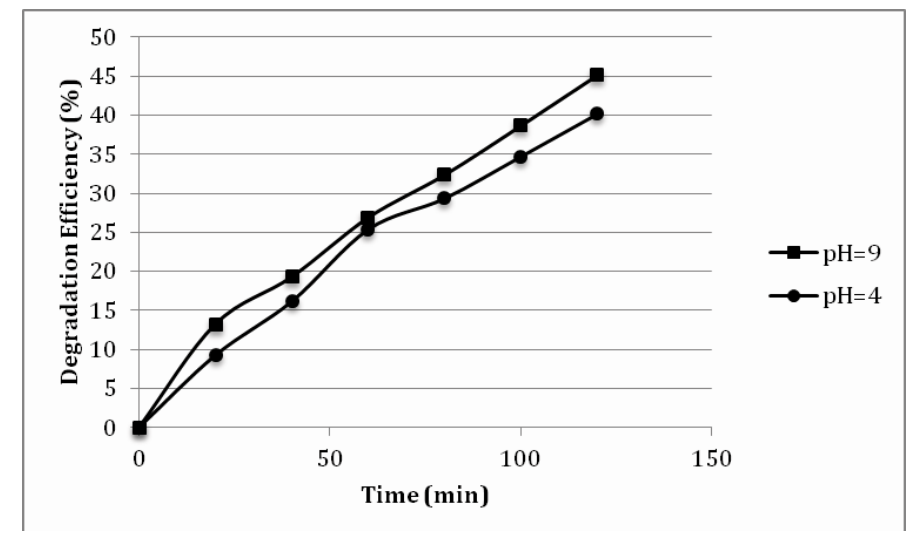

Fig. 6 The effect of $\mathrm{pH}$ on degradation of wastewater by $\mathrm{TiO}_{2} / \mathrm{H}_{2} \mathrm{O}_{2}$

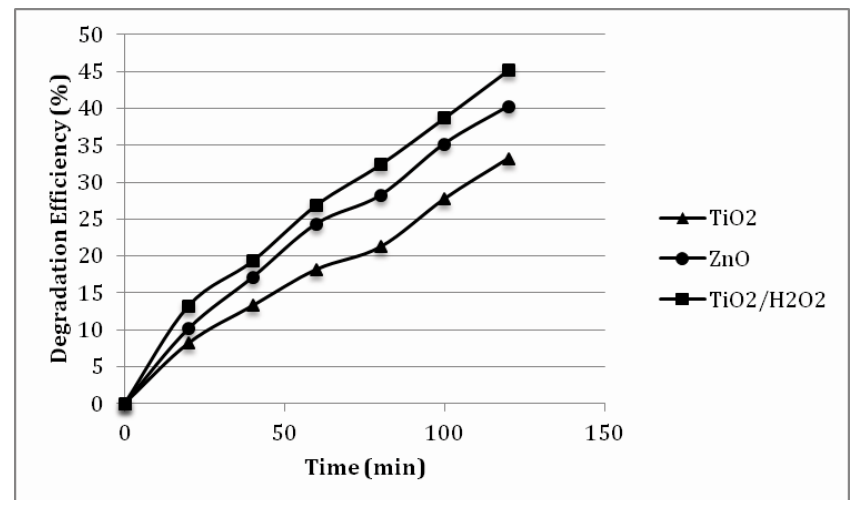

Fig. 7 The performance of catalyst at constant $\mathrm{pH}$ of 9

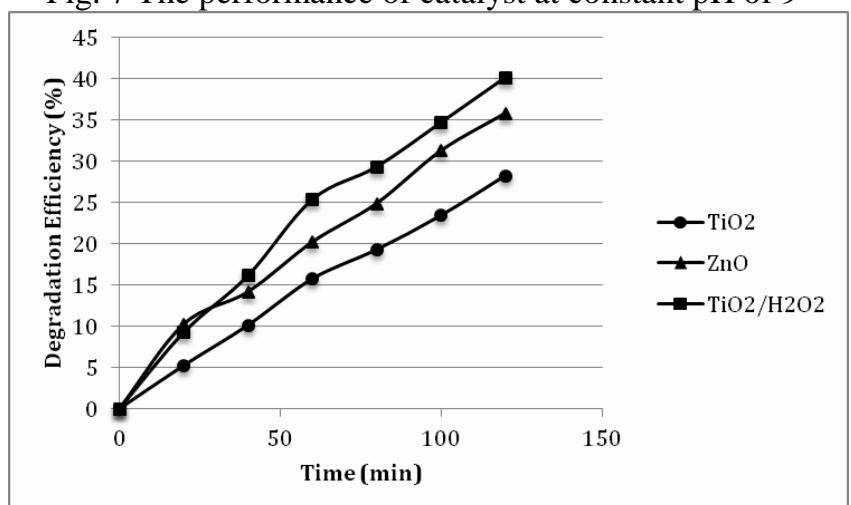

Fig. 8 The performance of catalyst at constant $\mathrm{pH}$ of 9

\subsection{Effect of reaction time}

A linear relationship as shown in Fig. 9 was observed between irradiation time and COD removal. The results show that in oxidation process, the reaction rate plays an important role than adsorption rate. The $\mathrm{OH}$ radicals can degrade organic pollutants to intermediates and then the intermediates are further degraded to $\mathrm{CO}_{2}$ and $\mathrm{H}_{2} \mathrm{O}$ [7]. The reaction rate attains a maximum value at high $\mathrm{pH}$; and the generation of $\mathrm{OH}^{-}$radicals by the effect of irradiation on the $\mathrm{TiO}_{2}$ of the composite may be another factor for increasing reaction rate in basic environment [1]. The maximum COD removal efficiency in $120 \mathrm{~min}$ was obtained at $\mathrm{pH}$ of 9 , which corresponds with the findings of San Sebastian [12,22]. The comparability of reported work on treatment of pharmaceutical in water and wastewater by AOPs with current study is given in TABLE 3. 


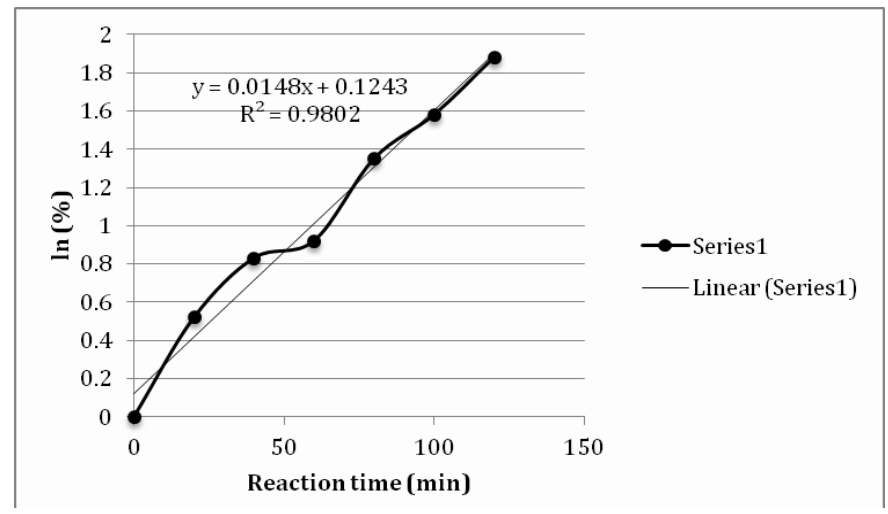

Fig. 9 The linear regression of degradation of pharmaceutical wastewater at $\mathrm{pH} 9$ and temperature $38{ }^{\circ} \mathrm{C}$

Table 3. Reported Work on Treatment of Pharmaceutical in Water and Wastewater by AOPS

\begin{tabular}{|c|c|c|c|c|c|}
\hline & AOPfeature & $\underline{\text { Scale }}$ & Measureof & Comparability & Reference \\
\hline Synthetic wastewater & $\mathrm{O}_{3}$ aloneorO $3 / \mathrm{H}_{2} \mathrm{O}_{2}$; & Bench & COD,TOC, & Yes & {$[8,9,16]$} \\
\hline Municinal & Ozalone & Pilat & TOC & $\mathrm{No}$ & Notlisted \\
\hline $\begin{array}{l}\text { Formulation } \\
\text { Effluent }\end{array}$ & $\begin{array}{c}\text { O3alone,UValone, } \\
\text { orO} 3 / \mathrm{H}_{2} \mathrm{O}_{2} ; \mathrm{Fe}^{2+} / \mathrm{H}_{2} \mathrm{O}_{2}\end{array}$ & Bench & $\begin{array}{l}\text { COD,TOC, } \\
\text { BOD5 }\end{array}$ & Yes & {$[9,15,16]$} \\
\hline $\begin{array}{c}\text { Syntheticwash- } \\
\text { waterfromantibiotic } \\
\text { packagingdistilled }\end{array}$ & O3alone, $\mathrm{O}_{3} / \mathrm{MnSO}_{4}$ & Bench & COD,BOD5 & No & Notlisted \\
\hline $\begin{array}{c}\text { Industrial wastewaterof } \\
\text { pharmaceutical origin }\end{array}$ & $\begin{array}{c}\text { UVonly, } \mathrm{Fe}^{2+} / \mathrm{H}_{2} \mathrm{O}_{2}, \\
\mathrm{UV} / \mathrm{H}_{2} \mathrm{O}_{2}\end{array}$ & Bench & COD,BOD & Yes & {$[5,12]$} \\
\hline Hospitalwastewater & $\mathrm{Fe}^{2+} / \mathrm{H}_{2} \mathrm{O} 2$ & Bench & COD,BOD5, & Yes & {$[31]$} \\
\hline $\begin{array}{c}\text { Syntheticwash- } \\
\text { waterfrommedium } \\
\text { scaledrug }\end{array}$ & $\mathrm{Fe}^{2+} / \mathrm{H}_{2} \mathrm{O}_{2}$ & $\begin{array}{l}\text { Bench } \\
\text { and } \\
\text { Full }\end{array}$ & COD,BOD5 & Yes & [17] \\
\hline $\begin{array}{c}\text { Biologicallypre- } \\
\text { treated pharmaceutical } \\
\text { wastewater }\end{array}$ & $\mathrm{Fe}^{2+} / \mathrm{H}_{2} \mathrm{O}_{2}$ & Bench & COD & Yes & {$[13]$} \\
\hline $\begin{array}{l}\text { Actualwash-water } \\
\text { fromointment } \\
\text { manufacturingplant }\end{array}$ & $\mathrm{Fe}^{2+} / \mathrm{H}_{2} \mathrm{O}_{2}$ & Bench & $\mathrm{COD}, \mathrm{BOD} 7$ & Yes & [14] \\
\hline $\begin{array}{c}\text { Effluentfrombulk } \\
\text { drugmanufacturing } \\
\text { plant }\end{array}$ & $\begin{array}{c}\mathrm{TiO} 2 \text { asanode, } \\
\text { Graphiteascathode, } \mathrm{Cl}^{-} \\
\text {aselectrolvte }\end{array}$ & Bench & COD,TOC & No & Notlisted \\
\hline $\begin{array}{c}\text { Distilled } \\
\text { water/Deionized } \\
\text { Water }\end{array}$ & 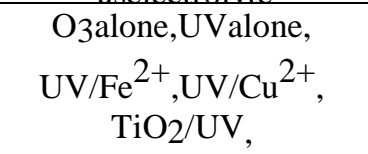 & Bench & TOC & No & Notlisted \\
\hline
\end{tabular}

\subsection{Kinetic analysis}

The linear regression analysis of degradation of pharmaceutical wastewater with $\mathrm{TiO}_{2} / \mathrm{H}_{2} \mathrm{O}_{2}$ at $\mathrm{pH} 9$ is shown in figure 9. The plotted data produced a straight line that indicates that the degradation of the pharmaceutical wastewater can be described by the following first-order kinetic model equation.

$\ln \left(\mathrm{C}_{\mathrm{o}} / \mathrm{C}_{\mathrm{t}}\right)=\mathrm{k}_{1} \mathrm{t}$

Where $\mathrm{C}_{\mathrm{O}}$ istheinitialconcentrationvalue,kisthereactionrate, andtisthetime.Theequation

(9)presentskineticexpressionandthecorrelationbetween $\ln \left(\mathrm{C}_{\mathrm{O}} / \mathrm{C}_{\mathrm{t}}\right)$ andreactiontimet linearwithR ${ }^{2}=0.9802$ for $\mathrm{TiO}_{2} / \mathrm{H}_{2} \mathrm{O}_{2}$. Thevalueofdeterminationcoefficient $\mathrm{R}^{2}$ clearlyindicates thatthisdegradationprocessfollowspseudo-first-orderkinetics. Thefigure9alsoshowstherate constant $(0.0148 / \mathrm{min})$. Theseresultsareveryclosetothefindingsof previousstudies[13,21,32].Morepreciserateof

SunJianHui[28].Similarto absorptionareincludedtothekineticmodelequation. 


\subsection{Pharmaceutical Wastewater and Mineralization Study}

The composition of pharmaceutical wastewater iscomplex andmaycontaindifferent typesof organicpollutants. Atthetimeofstudy,AbbotLaboratories wereprocessing formulations for antibiotics,analgesics, anti-inflammatorydrugsandCNSstimulantaslistedinTABLE1. Henceitis assumedthatthesamegroupofcompoundswouldbe presentin wastewater.TheHPLCresults confirmedtheconcentrationofthesecompoundslistedinTABLE 1.

During the degradation process, some intermediate products are formed which may be more difficult to degrade. The measurement of COD is related to total concentration of organic compounds in the waste and treated water. Hence the change in COD before and after treatment reflects degree of mineralization. The COD of sampled wastewater was in the range of 168 to $240 \mathrm{mgl} / \mathrm{l}$, which is within the standard discharge limits. However, the composition of the treated water suggests that nearly all of the intermediates were mineralized by photocatalysis under given conditions. It is most likely that the treated water is free from toxic compounds. This study confirms that photocatalytic degradation can completely mineralize pharmaceutical wastewater but still lacks in comprehensive study that encircles the comparison of the effect of $\mathrm{TiO}_{2}, \mathrm{ZnO}$, and other catalysts under different operating parameters. Therefore, in order to commercialize the photocatalytic wastewater technology, several key parameters like catalyst development, reactor design and process optimization need to be further investigated.

\section{CONCLUSIONS}

All three catalystsnamelyTitaniumdioxide,zincoxide, and $\mathrm{TiO}_{2} / \mathrm{H}_{2} \mathrm{O}_{2}$ usedinthisstudyare effectivecatalystsinphotocatalyticdegradationof realpharmaceuticalwastewater. However,the maximumdegradationachievedwas $45.11 \%$ bycombineduseofTiO andH $_{2} \mathrm{O}_{2}$ at $38^{\circ} \mathrm{CandpH}$ of9, within 120 minutes of irradiations. Withthesamecatalyst atpH of 4 thedegradation decreasedto35.82\%.Thedegradationat higherpHsupportsthenotionthatpHisoneofthemost

importantoperatingparameterthataffectthephotcatalyticreactivityof thecatalyst.Themaximum degradationwithZnOwas $40.23 \%$ andwithTiO ${ }_{2}$ was $33.23 \%$ atpH9.Thedegradationofthe pharmaceutical wastewater followedpseudo-first-orderkinetics.Thereactionrateconstantwas $0.0148 / \mathrm{minfor}$ $\mathrm{TiO}_{2} / \mathrm{H}_{2} \mathrm{O}_{2}$. Theresultsindicatethatforrealpharmaceuticalwastewater,combined useof $\mathrm{TiO}_{2} / \mathrm{H}_{2} \mathrm{O}_{2}$ is comparatively moreeffectivethan $\mathrm{ZnO}$ andTiO 2 alone.This study demonstrates thatrealpharmaceuticalwastewater reacts differently tocatalysts than synthetic pharmaceuticalwastewater,orformulatedwastewater.

Theresultsofthisstudyindicatedthatphotocatalyticdegradationcanbe usedforthereal pharmaceutical wastewater contaminated bydifferent inorganic-organic pollutants. Inorder to achievemorethan90\%degradation, pretreatedeffluentismoresuitableforAOPtreatment.Due to low consumptionofchemicalsand energy, heterogeneous photocatalysis seems to be a promisingmethodundermoderntechnologywithbroadapplicationin treatingwastewaterform pharmaceuticalindustry,hospitalsandmunicipalities.However,furtherstudiesare requiredfor i) identifying thebioactivity ofunknown intermediate products andby-products, ii)inhibition of photocatalyticactivitybynaturalorganicmatterpresentinthewastewater,andiii)comparisonof theeffectof $\mathrm{TiO}_{2}, \mathrm{ZnO}$, andothercatalystsunderdifferentoperatingparameters.

\section{ACKNOWLEDGEMENT}

This research study was funded by a research grant awarded by Higher Education Commission (HEC) of Pakistan under Foreign Professor Package Plan. We appreciate the chair and the administration of the Department of Chemical Engineering, University of Karachi, Pakistan for allowing us to use their research labs resources, analytical lab facilities, and making arrangements for the collection of wastewater samples used in this study from Abbot Laboratories (Private) Limited, Karachi.

\section{REFERENCES}

[1] Y. Liming, E.Y Liya, and B.R Madhumita, Degradation of paracetamol in aqueous solution by $\mathrm{TiO}_{2}$ photocatalysis, Water Research,42, 2008, 3480-3488.

[2] M. Addamo, V. Augugliaro, A. Di Paola, E. Garcia-Lopez, V. Loddo, G. Marci, and L. Palrisno, Removal of drugs in aqueous systems by Photoassisted degradation, Journal of Applied Electro Chemistry,35, 2012, 765-774. 
[3] C. Bozena and R. Katarzyna, $\mathrm{TiO}_{2^{-}}$assisted Photocatalytic degradation of diclofenac, metoprolol, estrone, and chloramphenicol as endocrine disruptors in water, Adsorption 2013, DOI 10 1007/s10450013-9485-8, 1-12

[4] K. Maria, M. Dionissios, and K. Despo, Removal of residual pharmaceuticals from aqueous systems by advanced oxidation processes: A review, Environment International, 35, 2009, 402-417.

[5] C. Hofl, C. Sigl, O.Specht, I. Wurdach, and D. Wahner, Oxidative degradation of AOX and COD by different advanced oxidation processes: a comparative study with two samples of a pharmaceutical wastewater, Water Sci. Technol.35, 1997, 257-264.

[6] Xu.Xiang-Rong,Li.Xiao-Yan,Li.Xiang-Zhong,andLi.Hua-Bin,Degradationofmelatonin byUV,UV/ $/ \mathrm{H}_{2} \mathrm{O}_{2}, \mathrm{Fe}^{2+} / \mathrm{H}_{2} \mathrm{O}_{2}$ andUV/ $/ \mathrm{Fe}^{2+} / \mathrm{H}_{2} \mathrm{O}_{2}$ processes,SeparationandPurification Technology, 68, 2009, 261-266.

[7] S.Fatemeh,Y.Mansouri,AAL Anilineusing $\mathrm{TiO}_{2} \mathrm{Nanoparticlesina}$ JournalofPhotoenergy, 2012, ID:430638,1-8.

Zintizadeh,andA.Akhbari,Photocatlyticdegradationof verticalcirculatingphotocatalyticreactor,International

[8] I.A.Balcioglu,andM.Otkar,Treatmentofpharmaceuticalwastewatercontainingantibiotics byO3 3 and $3 / \mathrm{H}_{2} \mathrm{O}_{2}$ processes, Chemosphere, 50, 2003, 85-95.

[9] I.Arslan-AlatonandA.ECaglayan,Toxicityandbiodegradabilityassessmentofrawand ozonatedprocainepenicillinGformulationeffluent,Ecotoxical,Environ.Saf,63, 2006, 131-140.

[10] S.Kaniou,K.Pitarakis, andI.Barlagianni,Photocatalyticoxidationofsulfamethazine, Chemosphere, 60, 2005, 372-380.

[11] [11]J.Hartmann,P.Bartels,U.Mau,M.Witter,W.V.Tumpling, and J.Hofmann,Degradation ofthedrugdiclofenacinwaterbysonolysisinpresenceofcatalysts,Chemosphere, 70, 2008, 453-461.

[12] N. San Sebastian Martinez, J.F.Fernandez, X.F. Segura, and A. Sanchez Ferrer, Pre-oxidation of an extremely polluted industrial wastewater by the Fenton's reagent, J. Hazard Mater, 101, 2003, 315-322.

[13] M.Xing,C.Deng,B.Godefroid,andJ.Yang,Treatmentofpharmaceuticalwastewater containingrecalcitrantcompoundsina Fenton-coagulationprocess,J.EnvironSci., 18, 2006, 459-463.

[14] N.Kulik,M.Trapido,A.Goi,Y.Veressinina,andR.Munter,CombinedChemicaltreatment ofpharmaceuticaleffluentsfrommedicalointmentproduction, Chemosphere, 70, 2008, 1525-1531.

[15] I.Arslan-AlatonandS.Dogruel,Pre-treatmentofpenicillinformulationeffluentbyadvanced oxidationprocesses,J.HazardMater, 112, 2004, 105-113.

[16] I.Arslan-AlatonandA.ECaglayan,OzonationofprocainepenicillinGformulationeffluent, PartI:processoptimizationandkinetics, Chemosphere, 59, 2005, 31-39.

[17] H.Tekin,O.Bilkay,S.SAtaberk,T.HBalta,I.HCeribasi,andF.DSanin,UseofFenton oxidationtoimprovethebiodegradationofapharmaceuticalwastewater,J.HazardMater, 136, 2006, 258-265.

[18] P.Calza,V.A.Sakkas,C.Medana,C.Baiocchi,A.Dimou,and E.Pelizzetti,Photocatlytic degradationstudyofdiclofenacoveraqueousTiO ${ }_{2}$ Suspension,Appl.Cata.BEnviron.,67, 2006, 197-205.

[19] O.Legrini,E.Oliveros, andA.MBraun,Photochemicalprocessesforwatertreatment,Chem. Rev.93, 1993, 671-698.

[20] APHA,AmericanPublicHealthAssociation,Washington,DC,USA,standardmethodsforexaminationofwate randwaste-waters, $17^{\text {th }}$ edition, 1989 .

[21] T.Ohno,K.Jarukawa,K.Tokieda,and M.Matsumura, Morphologyof aTiO 2 photocatalyst, (Degussa,Pconsistingofanataseandrutilecrystallinephases,JournalofCatalysis, 203, 2001, 82-86.

[22] K.Ilho,Y.Naoyuki,andT.Hiroaki,Photodegradationofpharmaceuticalsandpersonalcare productsduringUVandUV/ $\mathrm{H}_{2} \mathrm{O}_{2}$ treatments, Chemosphere, 77, 2009, 518-525.

[23] Y.Zhang,J.L.Ahong,and B.Ning,Photodegradationofestroneand17 $\beta$-estradiolinwater,WaterResearch, 41, 2007, 19-26.

[24] A. Almudena, J. B. Fernando, F. G-A. Juan, and O. Ana, Photocatalytic ozonation to remove the pharmaceutical diclofenae from waer: Influence of Variables, Chemical Engineering Journal,189, 2012, 275-282.

[25] CPCB,CentralPollutionControlBoard,MinistryofEnvironment(GovernmentofIndia),

[26] 2009,theenvironmentprotectionrules, 1986,page469; thirdamendmentofrulesin2009 notifiedbyG.S.R512(E)dated9.7.2009.

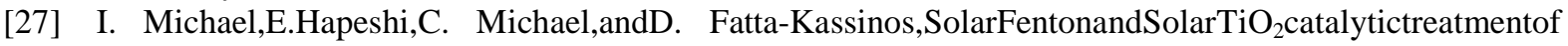
ofloxacinin secondarytreatedeffluents:Evaluationof operationaland kineticparameters, WaterResearch, 44, 2010, 5450-5462.

[28] G.Prados-Joya,M.Sanchez-Polo,J.Rivera-Utrilla,andM.Ferro-garcia, Photodegradationof antibioticsnitroimidazolesinaqueoussolutionbyultravioletradiation,WaterResearch, 45, 2011, 393-403. 
[29] J.H.Sun,J.L.Feng,S.H.Shi,Y.Q.Pi,M.K.Song,andY.Shi,

Degradationof aqueoussolutionbyphoto-Fentonoxidation,Environmental sulfamonomethoxinesodiumin Science\&Technology,57, 2012, 558-564.

[30] T.Tao,Q.Kun,S.Tianyu,W.Fang,L.Pingliang,L.Jianqiang,andC.Yongsong, quinestrolinwatersandthetransformationproductsbyUVirradiation, Chemosphere, 89, 2012, 1419-1425.

[31] J.J.Yeon,G.K.Wan,Y.Yeojoon,K.Joon-Wun,M.H.Young,andW.K.Hyun, amoxicillinbyUV/ $\mathrm{H}_{2} \mathrm{O}_{2}$ processes,ScienceoftheTotalEnvironment,420, 2012, 160-167.

[32] P.KajitvichyanukulandN.Suntronvipart,

Evaluationofbiodegradabilityandoxidation degreeofhospitalwastewaterusingphoto-Fentonprocessasthepretreatmentmethod,J.Hazard Mater,138, 2006, 384-391.

[33] H.F. Fritz and E.D. Tusnelda, Xenobiotic pharmaceuticals in water and methods to prevent their appearance in drinking water, Soil and Water Pollution Monitoring, Protection and Remediation, 3(23), 2006, 339-349. 